\title{
DEVELOPING A TOOL FOR QUALITY AND ACCREDITATION OF A NEW GENERATION UNIVERSITY IN THE DIGITALIZED SOCIETY: THE CASE OF A THEMATIC-TECHNICAL UNIVERSITY*
}

\author{
Metin Toprak ${ }^{1}$, Yüksel Bayraktar ${ }^{1}$, Armağan Erdoğan², \\ Deniz Kolat ${ }^{3}$, Mehmet Şengül ${ }^{4}$
}

date of paper receipt:

30.04.2019.

Review Article date of sending to review:

03.05.2019.

doi: 10.2478/eoik-2019-0017 date of review receipt:

23.05.2019.

UDK: $378.014 .3 / .4$

${ }^{1}$ Istanbul University, Department of Economics, Turkey

${ }^{2}$ Social Sciences University of Ankara, Faculty of Foreign Languages, Department of English Language and Literature, Turkey

${ }^{3}$ Batman University, Vocational Higher School, Program of Banking and Insurance, Turkey

${ }^{4}$ Mustafa Kemal University, Rectorate, Turkey

${ }^{\star}$ This study is based on a project supported by The Ostim Technical University (Turkey). We are thankful for its support.

\section{ABSTRACT}

In Turkey, digitalization of curricula, teachers, course materials, and educational technologies is relatively slower when compared with the ones in economic sectors and state services in general. In this study, we proposed a model for a new generation university in a digitalized society. The Council of Higher Education classifies universities in three categories (mission) to respond to technological and economic developments in the societal life: research, regional-development oriented and thematic universities. At national level, a digital transformation office acts as a coordination and orchestration body among governmental institutions in order to carry and transform public services into digital environment. The private sector naturally has to be digitalized by national and international severe competition.

The tool developed in this study based on the model developed by Toprak et al. (2019). That model aims to compensate for coordination gaps in the traditional university hierarchical structure, which is designed as department, faculty board, university board and senate, from administration to governance. Five innovations can be mentioned in terms of organizational and functional configuration of a university model proposed there: (i) profile of graduate and mission of the new generation university in the fields of education, research and community services, (ii) policy development and implementation offices, (iii) university ecosystem consultation and steering committee and other committees and boards, (iv) concept courses and branded courses, (v) coop education and solution partnerships. The Rector's Office acts as an executive committee to prevent coordination gap in the proposed model.

A checklist has been developed for the processing of that model and hence it is made possible to measure the performance of an applied university and degree of compatibility with the model. Thus, the framework and content of the mechanism and tools traditionally used in quality assurance and accreditation will need to be updated in line with this model.

\section{Keywords:}

New generation university, university 4.0, university governance, digital society, mission university. 


\section{INTRODUCTION: MOTIVATION AND RESOURCE}

The digitalization phenomenon presents a challenge for economic sectors, state services, and education in all societies if they fail to implement the appropriate digitalization strategies. Digitalization of media, production and thinking brings new opportunities to the societies adopting it well and introduces threats to those lagging behind. The term "information and communication technologies" is enriched and updated with new explanations and inspirations on a daily basis. Education system of a country is the only asset that enables or disables that country to be updated or outdated.

Turkey officially changed its system of governance with the 2018 presidential and parliamentary election. Presidential government system introduced a new model based on four pillars:

(i) ministries,

(ii) offices,

(iii) policy boards,

(iv) directorates.

After almost one year of its implementation, it has now been discovered that the necessary mechanisms and instruments to ensure that the working of the system was not designed and integrated into the system before it took effect. However, the design of the new government system is in line with the agenda of the EU 2020 and especially digital Europe vision. Since Turkey is an official candidate for the EU, all measures and items on the EU agenda are compulsory to be implemented by Turkey. It is evident that fancy and trendy systems and visions are necessary but not sufficient for upgrading and updating a system, and adequacy of human resources is also crucial. Ostim Technical University (OTU) is newly established (2017) and getting ready to be fully functioning in the 2019 Fall semester. Our research team was asked to develop a university model compatible with the European Higher Education Area (EHEA) reform topics: 21st century skills (Cedefop, 2016; Shapiro, Lauritzen and Irving, 2011; Erdoğan and Toprak, 2014; Holtzman and Kraft, 2011), active participation of stakeholders (Chapleo and Sims, 2010), and corporate governance principles (OECD-IMHE, 2009; Toprak and Bayraktar, 2017). A model and its checklist have been developed (Toprak et al., 2019). In this study, the model developed is summarized and the comprehensive checklist is detailed with its various dimensions. Turkish University system has been adopting EHEA agenda since 2001 when Turkey became a signatory of the Bologna Process (EHEA, 1998, 2018, 2019). The model of OTU constitution (statute) was developed by the research team based on the approach developed for a new generation university (Ostim Technical University, 2018).

The main data source for specifying dimensions, parameters and variables used in this study is the group of experts in various fields in Turkish universities. During establishing a practicebased education model and curricula of study programs, checklist dimensions and items were also developed simultaneously. The expert group consisting of a total of 20 people evaluated early drafts of the tool (checklist) and then the tool was finalized based on the suggestions of this group of experts. The checklist developed in this study would rather be used for accreditation and institutional evaluation.

\section{THE NEED FOR NEW UNDERSTANDING AND NEW MODEL IN THE UNIVERSITY SYSTEM}

Whether universities have the necessary mechanisms and instruments to fill the gap between industry and university is a hot topic of discussion in Turkey. The direct access to an entrepreneurial university must begin with governmental initiation. Then industry \& university collaboration will follow the first step. Thus, government-university-industry triple helix will be an interactive mechanism that is assumingly synergetic. The last step in the process will be on demand coming 
from industry to university and thus university-pushed triple helix will occur (Bizri et al., 2019; Etzkowitz et al., 2013; Zhou, 2008). The main benefit expected from triple helix is the synergy accruing from normative control of government, wealth generation of industry and novelty production of university (Murphy, 2011; Lee, 2011; Lu, 2008; Ughetto, 2007). The 4th generation university model slightly differs from triple helix paradigm and includes one more dimension, i.e., society (Savignon, 2018; Scalia, 2018; Galvão et al., 2017; Yang and Holgaard, 2012).

Technological improvements, deeper understanding of tertiary governance systems in terms of their organizational and functional architecture, and experience of the research team in implementation of the EHEA reform topics in Turkey allowed the compilation of a holistic model for a new generation university model and its checklist that can be used by quality assurance units and accreditation agencies. However, the main obstacle against the employment of this mechanism would be intellectual capital in decision making bodies in higher education sector (Lombardi et al., 2019; Kabashkin, 2018; Dewar, 2017; Kireçci et al., 2016; Toprak and Erdoğan, 2013; Toprak, Erdoğan and Açıkgöz, 2013; Baker and Henson, 2010; Hawkins, 2000). The holistic approach consists of the following components and framework:

1. Centrally regulated and supervised with an active participation of stakeholders, and autonomously operating units, offices and committees (integrated governance through information technologies),

2. Higher interaction of units and committees (internal-external, horizontal-vertical),

3. Effective stakeholders' engagement (public sector, business world, employees, alumni, education and training staff, students),

4. High diversity (staff and student),

5. Based on competitiveness,

6. Focusing on change \& innovation and a high degree of interdependence,

7. Focusing on production and commercialization,

8. Adopting a utilitarian philosophy,

9. The outcome-oriented (reviewing the processes according to the result) to equip the alumni with the necessary knowledge and skills to ensure competencies for employability.

10. Based on pre-established standards (qualifications framework, professional / occupational standards, core competencies),

11. Ensuring quality assurance,

12. High accountability to the community (public) and other stakeholders,

13. Focusing on learning by doing and on the job training,

14. Implementing internationalization as a priority dimension,

15. Not neglecting the social dimension (considering the needs of disadvantaged groups and individuals).

\section{RESEARCH PROBLEM, RESEARCH TEAM, DATA SOURCES}

The problem of this study can be formulated as Why does (the Council of Higher Education (CoHE) try to direct universities by linking them with research and regional development, and Why are Turkish universities lagging behind in comparison to peer universities in Europe? Our hypothesis is the organizational and functional structuring and operating model of Turkish universities is the main factor in comparatively inadequate performance.

Due to their duties, the researchers who make this study spend a significant portion of their work in the fields and subjects mentioned above. In addition, the research team also included experts in various fields while developing curricula. The university model established in this study is called applied thematic-technical new generation university.

The research team consists of researchers working in the vocational education and reforms in higher education at the national level. The research team has involved directly and deeply in the 
development of Turkish Qualifications Framework (CEC, 2015), qualifications framework of Turkish higher education institutions (Council of Higher Education, 2010), national occupational standards (CEC, 2019) and quality assurance. Therefore, the research team is competent due to this direct engagement. Considering the organizational and functional architecture envisaged in the Law No. 2547, it was considered that it is possible to develop a model within the framework of existing legal and institutional arrangements without requiring legal changes. Therefore, a university model based on international and national developments in the fields and subjects identified as the vision above has been designed.

\section{DIMENSIONS OF GOVERNANCE MODEL OF A NEW GENERATION UNIVERSITY}

The new generation model developed is not presented in this study. However, via evaluation checklist, main parameters and variables can be easily detected. A checklist has been developed to evaluate performance and adaptation of the new generation university (NGU) to changing conditions (EC, 2017; Alan, 2016; Erdoğan and Toprak, 2012; Deema, Mokb and Lucasa, 2008). Mechanisms and instruments of the NGU are supposed to update inputs, processes and outcomes automatically via traditional academic / administrative units, newly introduced offices, committees, solution partnerships and concept / branded courses. The following dimensions will be evaluated in the context of NGU in the stages of quality assurance and accreditation assessment:

\subsection{BRIEF INTRODUCTION OF THE UNIVERSITY}

Every university has a welcome note to its stakeholders and assessors. Here, the university is introduced to the evaluator briefly such as university's motto, the nature of education and the greeting message to the general audience. Thus, it will be possible to get the first impression of the university to be evaluated.

\subsection{DESCRIPTION OF PRACTICE-BASED EDUCATION}

A general short description of the practice-based education that the university has adopted is given under this title, and during the evaluation it will be taken as benchmark. The concept of practice-based education covers on-the-job-training, work-based training, learning by doing, laboratory work and workshop. Learning outcomes are evidence-based. Practice-based education approach describes systemic and systematic model in terms of framework, content, mechanisms and instruments. With this holistic model, it will be possible to secure the vision of the university and guarantee the realization of its objectives. For the impact of practice-based education on the university organizational and functional operating model (Artut and Bal, 2018; Estébanez, 2017; Cedefop. 2016; Drewery, Nevison and Pretti, 2016; Johnson, Johnson and Smith, 2013; Cedercreutz and Cates, 2010; Bulut, 2010; Johnson, Johnson and Holubec; 2008; Haddara and Skanes, 2007; and Barbeau, 1973).

\subsection{VISION AND PURPOSE}

The university's vision is to teach its students at the international standards, deliver practice-based education and adequate social \& physical infrastructure. It aims to have graduates who are able to work effectively in projects, designing, entrepreneurship and innovation. Sensitivity to social and cultural issues is another strength of the education it delivers.

The university aims at delivering skill-based, vocationally-oriented and learner-centered education. All social stakeholders actively participate in the educational processes. Commercialization / 
branding, patent, design, and copyrights complement the education system at the university. Knowledge production is, in principle, project-based and research-based (Piirainen, Andersen and Andersen, 2016; Deus, Battistelle and da Silva. 2016; Reyes, 2016; Striukova and Rayna, 2015; Liu, 2012; Weenen, 2000).

\subsection{OUTLINE OF THE UNIVERSITY'S PRACTICE-BASED EDUCATION MODEL}

In the practice-based education model, education and research are intertwined with implementation and industry, and feedback mechanisms are internal to the system. The university is positioned as an integral part of the ecosystem. In this way, it will be ensured that the university is motivated to keep itself up to date due to interactive communication with internal and external stakeholders.

Criteria for evaluating the design and performance of the concept of practice-based education can be summarized as follows according to the framework given in the appendix.

Profile of the graduate is one of the key factors in any education model. The intention and direction of the education program may easily be detected based on designation of profile(s) of graduates. For instance, graduate of management program may have four types of graduates: - accountingfinance-commercial law; -management and commercial law; - production management and marketing; and - quantitative methods. However, there is only one profile of graduate foreseen at bachelor's degree in general.

Design of curriculum is a multi-dimensional phenomenon: the ratio of compulsory-elective courses, the design of the concept and branded courses, and compatibility level of the design curriculum with the vision and aims of the university. The ratios of compulsory and elective courses directly affect the designation of curriculum and share of concept and branded courses. National regulations and occupational standards must be considered in designing the model. The changing ratios of theoretical, application and competence-based courses thru education years are directly related to the model chosen. While cornerstone courses are mainly theory and instrument (statistics, quantitative decision-making techniques etc.) oriented, capstone courses are mostly job market and skills oriented. The teaching and learning ways and the environments of education and training can give strong clues regarding the characteristics of the model. Classroom, laboratory, multimedia, workshop, company (university owned or outside university) are main places for the model. The share of each of these places in both theory-based and practice-based courses also show if the model is really practice based.

Compatibilities with modular design of curriculum, compliance with profile differentiation, suitability for field diversification / differentiation, and eligibility to improve the social dimension are elements in the cross-check tool if design of curriculum allows the practice-based model.

In the new generation university model, a university is assumed to specify some concepts that its graduates will have some distinguished skills and competences that coming from education of these concepts. For example, a thematic technical university allows the following concepts to be obtained by its graduates at various levels and contents: idea and concept of design; project / process design and management; R \& D and innovation; algorithm and coding; entrepreneurship, leadership, coaching, mentoring and tendency to innovation; preparation to business world; transformational history of industry and company; environmental sustainability and sustainable development; digital media, communication design and content production; and quality assurance. All these concepts must be considered during curriculum formation and updating.

In the new generation university model, collaboration of the university with the industry goes toward the model of "educating and training students together". The university may specify some courses provided by the industry (associations, companies, public institutions, NGOs, etc.). The branded courses determined by the thematic-technical university are as follows: occupational law and regulations (related profession); financial technology; international trade and taxation; insurance management; participation (Islamic) banking; commercial banking; digital marketing; digital media, communication design and content production; IT management in business; health, safety and environmental management; supply chain and logistics; network systems engineering; 
advanced web technology; big data analysis; forensic IT; cloud computing and applications; IoT and Industry 4.0; application development for android devices; and graphics and design.

Regulatory framework has inside and outside dimensions. National regulations and frameworks (outside) are mandatory for all higher education institutions and institutional regulations (inside) must be in line with national ones. If national regulations are not flexible enough, it is quite hard to implement a uniquely developed model without going around. European and hence Turkish regulations and frameworks are quite flexible and allow a wide diversity in designing programs. The following items are the main components of a checklist while assessing national regulations: Actuality, the degree of allowing profile differentiation, applicability, compliance with international standards, and innovative aspect.

The institutional regulation regarding a study program is program key learning outcomes (PKLOs). After assuring the compatibility of PKLOs with national frameworks, content designation and learning outcomes (LOs) of the individual courses can be described in line with PKLOs.

In evaluating PKLOs if they allow effective practice-based education model the following items are assessed: actuality; compliance with international standards; knowledge propositions; skill propositions; propositions for taking responsibility and working autonomously; stakeholder engagement; consistency of goal, context and verb; applicability / feasibility; originality; the degree of allowing profile differentiation; innovative aspect; learning and teaching environments and methods; measurement and evaluation methods; environments and methods of theoretical education; environments and methods of practical education.

Design and feasibility of solution partnership must be in line with the practical training model. The following items are taken into account during evaluation: inclusion of relevant stakeholders in designing solution partnerships; feasibility / applicability; suitability of defined solution partnerships for education \& training; eligibility of defined solution partnerships for project and research; suitability of defined solution partnerships for practice; suitability of defined solution partnerships for skill development; and cost advantages / disadvantages of defined solution partnerships over traditional education system.

In the context of thematic \& technical university model, the most probable solution partnerships are following: tutorials; laboratory; multimedia laboratory; foreign language; workshop; practice (workplace: 'industry'); skill development (workplace: workshop at university garage / hangar); employment; project development; product and service development; R\&D and innovation; curriculum update and program development; Vocational Qualifications Authority (VQA) standards and qualifications; 21st century skills; national and global network design and management; entrepreneurship and leadership; broadcast development; equal opportunity and ethical issues; disadvantaged; digital agenda; quality assurance and accreditation; and internal control and internal audit.

Potential and capacity of a university is crucial to make the practice-based model successful. The degree of the physical, financial and infrastructural facilities of the university must allow the practice-based education model. In addition, the degree of the academic and research staff of the university must be enough to implement the relatively higher cost model. While assessing the facilities of a university regarding its potential and capacity the leading items are following: research \& publication performance, field experience and educational background of academics and research staff; university financial capacity and opportunities allocated to education and research; physical environment, social facilities, transportation, and housing; laboratory, IT infrastructure, and library; and adequacy and readiness of network and ecosystem outside the university.

All the above explanations related to type of courses, design of curriculum, engagement of stakeholders and solution partnerships affect directly the design of the teaching and learning ways. By assessing teaching and learning ways obtained from implementation of teaching and learning ways can give direct indicators if the model is effective practice-based.

When talking about the content and tools of practice-based education \& training model, we also imply organizational and functional structure and operating model. Beside committees and boards, policy development and implementation offices are also envisaged as new units. In traditional 
university system program, department, faculty and rectorate are envisaged and hierarchy is quite simple and mostly vertical. In the new generation model new offices, committees and stakeholders must involve all decision making, implementation and revision processes. In order to assure this effective functioning and involvement of stakeholders in the committees and boards the following criteria must be assured in the establishment and functioning: the relationship between the university purpose and vision; stakeholder engagement; accountability; applicability of decisions; consistency of the operating model; effectiveness of the operating model; focus on output; and focus on process. It is very important to whom or to which units these committees / boards will report, or which units or persons will report to these committees / boards. The list of committees / boards is provided in the appendix. New functions and responsibilities of a new generation university necessitate intermediary committees and bodies. The committees / boards envisaged here are designed to fill the gap resulting from coordination, cooperation and implementation processes of traditional and new generation units. (Toprak et al., 2019).

The other important organizational and functional new units are policy development and implementation offices. The following offices are assumed to fill the gap in the traditional university structure: strategy development, standards and quality assurance office; external relations office; project development and management office; technology transfer office; career planning and on-the-job training office; business and alumni relations office; entrepreneurship and leadership office; new jobs and new skills office; lifelong learning office; internal control and internal audit office. In order to assess to what extent the design of policy development and implementation offices contribute to the practical training model, the following items can be used: the relationship between the university purpose and vision; stakeholder engagement; accountability; applicability of decisions; consistency of the operating model; effectiveness of the operating model; output orientation; and process orientation.

The comprehensive illustration that portrays all items in the governance model of the new generation university model panoramically is given at Figure 1.

\subsection{PROFILE OF GRADUATE}

Single or multiple alumni profiles can be designed in the curriculum on modular system. The type and design of the alumna profile are determined through the consensus and active participation of the stakeholders in line with the needs of the business world and the framework of the curriculum (Kulkarni and Kulkarni, 2019; McRae and Ramji, 2017; Patton, 2017; Wagenaar, 2016; Sheety et al., 2016; Bruton, 2014; Sumanjeet, 2012; Holtzman and Kraft, 2011; EC, 2010; Wagner, 2009; EC, 2008).

Each course in the practice-based education model is designed in three dimensions: theory, practice and competency. In terms of these three dimensions, the average ratios are calculated as follows (for the management program):

for the theoretical part $\quad: 56,2 \%$

for the practice-based part $\quad: 30,0 \%$

for the competency part $\quad: 13,8 \%$

\subsection{THE KNOWLEDGE, SKILLS AND COMPETENCE DIMENSIONS OF THE CURRICULUM}

In a bachelor's degree program (the pilot program as an example), while the ratio of theoretical education gradually decreases over the years, the skills and competency dimensions increase. In our example (management program), the share of the theoretical part in the curriculum decreased from $74 \%$ in the 1 st year to $33 \%$ in the last year. While the share of the practice-based education in the curriculum is $17 \%$ in the 1 st year, it increases to $51 \%$ in the last year. Similarly, the share of competency in the curriculum is $9 \%$ in the 1 st year and $16 \%$ in the last year. 


\subsection{THE WAYS COURSES ARE TAUGHT}

The way in which the theoretical parts of courses or pure theoretical courses are given, or the environments in which the knowledge gained in the classroom environment are differentiated in the practice-based education model. In the acquisition of theoretical knowledge, learning by doing environments (laboratory, multimedia environment, workshop, companies) and skill development classrooms (solution partnerships of the personnel of the university staff) are expected to play an important role.

\subsection{QUALIFICATION INFORMATION FORM}

The content design of the diploma information form, or alias qualification information form provides important clues about the effectiveness of the practice-based education model. The level of the design and implementation of the concept of the practice-based education model can easily be tracked in this form.

\subsection{UNIVERSITY POSSIBILITIES AND CAPABILITIES}

The practice-based education model needs more attention of managers of university and program as well as academic staff, in terms of program design, implementation, monitoring and review. In addition to financial opportunities, research and education infrastructure, qualified academic staff brings higher education cost. Practice-based experience, project skills and competency of lecturers and research staff are much more demanding when compared to traditional classroombased system. However, in case of lack of infrastructure and qualified teaching staff required by the practice-based education model, the risk of failure of the model is quite high and the academic competency of the alumni tends to worsen.

\subsection{TURKISH HIGHER EDUCATION QUALIFICATIONS FRAMEWORK DESIGN AND PRACTICE-BASED EDUCATION}

The Turkish Higher Education Qualification Framework (TQF-HE) is developed by the CoHE, which is the national regulatory and supervisory authority for higher education system in Turkey. The level of compliance of practice-based education model with TQF-HE is critical. Since practicebased education means a significant balance shift in terms of knowledge and skills \& competences; LOs described in the TQF-HE should allow this shift. For this reason, not only curricula of education program but TQF-HE should also be reconsidered.

\subsection{PROGRAM KEY LEARNING OUTCOMES}

The program key learning outcomes (PKLOs) indicate the knowledge, skills and competencies that graduates of an education program will have. The analysis of the PKLOs gives an idea about the profile of the program, the profile of graduates and the orientation of education. The scope of the practice-based education model will affect the PKLOs structurally. For this reason, PKLOs are vital in evaluating a program which describes the profile of the graduate.

\subsection{RELATIONSHIP BETWEEN PKLO AND TQF-HE}

PKLOs are more concrete and specific than the TQF-HE level descriptors. In evaluating the compliance of practice-based education model with PKLOs and TQF-HE; the weights are 0,75 for PKLOs and 0,25 for TQF-HE. 


\subsection{COURSE LEARNING OUTCOMES}

The course learning outcomes (CLOs) show the scope of the course, the way it is taught, the relative position of the course in the curriculum, the set of knowledge, skills and competences acquired by the students and the environments and forms of acquisition of this set. CLOs are more concrete, observable, measurable and comparable than PKLOs. It should be possible to set a relationship between CLOs and PKLOs and conclude whether PKLOs are based on solid foundations.

\subsection{THE RELATIONSHIP OF CLOS AND PKLOS}

Since CLOs are more concrete and specific than PKLOs, in the evaluating compatibility of CLOs and PKLOs with the practice-based education model, the weight ratio of CLOs is higher than that of PKLOs. In evaluating compliance of practice-based education model with CLOs and PKLOs; the weights are 0,75 for CLOs and 0,25 for PKLOs.

\subsection{COMPULSORY-ELECTIVE COURSE RATIO}

The ratios of compulsory courses and elective courses in total significantly determine the composition of major, minor or double major. Organizing elective courses on the basis of individual courses (at the level of program, faculty or university) or on the basis of modules (bundle of courses) depends on the profiles of the program and the graduate.

\subsection{COMPULSORY-ELECTIVE COURSE DESIGN}

Designing compulsory and elective courses in line with the practice-based education model is critical in terms of program profile and graduate profile. While designing the compulsory and elective courses, the following points are critical: the thematic and sequential relationship between compulsory courses, the relation of education program with other ISCED detailed and narrow fields, the conformity with the modular design, the design as concept courses and branded courses, and the design in the form of professional proficiency certificate programs.

\subsection{DESIGN OF SOLUTION PARTNERSHIP}

In the practice-based education model, it is not possible for the university to equip its students with the prescribed outcomes, to carry out research and projects only with its own means. All social stakeholders in the ecosystem are expected to take part in education at different levels in the practice-based education model. Stakeholders need to be in close cooperation with the university programs in the fields of education, research, projects, laboratories, workshops, internships, etc. University governance model should take corporate governance principles into consideration while designing new generation committees \& boards policy development and implementation offices, solution partnerships, concept and branded courses. This is a key factor for a successful model (Cozza and Blessinger, 2016a; Cozza and Blessinger, 2016b; Liu and Kong, 2015; Toprak and Erdoğan, 2012; Antal et al., 2014; Macpherson, 1997).

\subsection{CONCEPT COURSES AND BRANDED COURSES RATIOS}

Concept courses play a critical role in the realization of the vision and purpose of the university, which is the fundamental justification of the foundation of the university. The proportion of concept courses and branded courses in the curriculum is also an important indicator for the profile of the graduates (Gartland and Smith, 2018; Olsson, 2016; Poon and Brownlow, 2015; Farnsworth, 1970). 


\subsection{DESIGN OF CONCEPT COURSES}

The concept courses differentiate the university from other universities in terms of the vision and the purpose. The privilege of graduates is mainly based on the outcomes acquired via concept courses. That the graduates of the university can be expected to be positively treated and accepted by employers since they have learning outcomes acquired thru concept courses. The concept courses in the curriculum are developed based on a wide consultation and direct evaluations of the business world (Hasan et al., 2017; Rubens et al., 2017; Bacanlı et al., 2016; Marri et al., 2002). Design (innovative thinking, multi-dimensional thinking); algorithm and coding (CIT, computing technologies and cloud computing, data base analysis); project / process planning and management; $\mathrm{R} \& \mathrm{D}$ and innovation (process from idea to product: "patent, trademark, license"); entrepreneurship and leadership; preparation for business world; environmental sustainability and sustainable development; digital marketing, communication design, content production and quality assurance have been determined as the concepts of the university.

While preparing curricula for the university's diploma and certificate programs, the above thematic concepts will need to be designed individually or as a combination of course, practice, internship, project, research and community service activity. These thematic concepts will be transformed into output in the form of academic competencies that the graduates are assumed to have. As an authenticity of the thematic applied university, it is envisaged that an office and committee will work in order to successfully implement and update these thematic concepts determined by a wide consultation.

It can be said that, the thematic concepts emphasized by a university aiming to be established within the organized industrial zone (OIZ) are not designed in national or international qualifications frameworks following the aforementioned approach. Therefore, when the thematic university is in question, it is necessary for national authorities to encourage such conceptual priorities. A university operating in the OIZ and specifying a unique set of concepts does not necessarily exclude other common / popular competencies. For example, it is not a handicap for any thematic university to acquire the competencies developed as the 21 st century skills in all higher education programs besides the university-specific concepts.

Since the spectrum of the concept courses is remarkably wide, it is not economically feasible to have students achieve the predetermined learning outcomes of conceptual courses only by a university's own means. In fact, in the practice-based education model, active participation of the related stakeholders in the processes is essential. Stakeholders who have potential and capacity in some concept courses should play an active role to help students to acquire these competencies. Since the implementation of these concept courses is quite costly, the critical point here is implementing an operating model in the design of these concepts. The main reason for practice-based education is based on the deficiencies of the graduate in these concepts. Therefore, designing, implementing, reviewing and updating of the concept courses is a priority.

Recognition of prior learning is an instrument that is essential in the practice-based education model. Since student learning takes place in the practice environment, unplanned and unintended learning is also expected to occur frequently. In this case, implementation of the RPL approach will be an important source of motivation for students' learning.

\subsection{DESIGN OF BRANDED COURSES}

One noteworthy phenomenon in industry-oriented universities is the application of branded courses. Famous brands are opening courses to promote and disseminate their soft or hard products. These courses are given mostly by the professionals in these companies. This application, which is a new form of university - industry interaction, is predicted to create a significant synergy through feedback. For example, Microsoft offers more than a dozen of courses in the field of information and communication technologies in the Microsoft Virtual Academy platform. It is also possible to make assessment of these courses in accredited Microsoft exam centers. 
Globally manufacturing companies, especially those in the technology and IT sectors, have significant competitive advantages and wide and integrated product range in the market. These companies frequently develop strategies that can lead to market closure.

Companies such as Microsoft, Apple and IBM bring an important step to vocational education and university education with the course modules they develop. For example, the courses offered by Microsoft cover almost half of the university program on computer science. Since this trend will continue to be evident, designing and incorporating products and brands of companies that are significantly influential in the global market as courses or modules (bundle of courses) will provide a significant advantage for graduates in entering the labor market. It is of strategic importance that the subjects that overlap with the university education programs should be designed as courses and modules and these proposals should be offered to companies when necessary.

\subsection{ORGANIZATION AND GOVERNANCE MODEL}

\subsubsection{COMMITTEES AND BOARDS}

In the organizational and functional architecture of the traditional university, hierarchical structure is defined at the program, faculty and rectorate levels. Duties, authorities and responsibilities are also well defined. Therefore, policies aimed at directing universities to research, project, innovation and new generation learning technologies at national level in recent years cannot be at the desired speed and scale.

Subjects such as the concept courses, branded courses, recognition of prior learning, the policy development and implementation offices which constitute the basis of the practice-based education model are complementary to the traditional university organization and operating model because it is not possible to reach the desired result by only traditional organizational structures and functions. The committees and boards will need to be designed and operated as complementary and supportive. The most effective way of stakeholders' active engagement will be the creation and operation of committees and boards, and these bodies will be the most important instrument for the university system to remain updated and dynamic (Lombardi et al., 2019; Dewing and Williams, 1995).

\subsubsection{POLICY DEVELOPMENT AND IMPLEMENTATION OFFICES}

Creating new generation offices, committees and boards is crucial in the implementation of new academic and administrative functions and tasks not found in the traditional university organization and operating model. To call these offices as administrative or academic offices does not seem proper because both academic staff and subject matter expert staff will work together in these offices. Therefore, traditional classification of academic and administrative staff does not serve the purpose and their positions within the university organization should be determined appropriately. Policy development and implementation offices are important in terms of ensuring active stakeholder participation, keeping the education programs and the university agenda up-to-date and proactive. These offices and committees are also necessary for implementing corporate governance principles in the most effective manner. If these offices or committees are not functioning effectively, the benefits designed for the practice-based education model within the traditional university system cannot be obtained. Even worse, the new model may cause excessive bureaucracy and unnecessary paperwork (Block and Khvatova, 2017; Otala, 1994).

\subsubsection{GOVERNANCE MODEL}

The Ostim Technical University, which positions itself as a new generation institution and focuses on practice-based education, with new organizational units and new functions added to the traditional university organizations and functions, will have quite complicated structure and functions. As it is not possible to change the legally-regulated subjects with the decisions of the university, it is necessary to develop a hybrid structure and operation in accordance with the laws and regulations as well as the application of the new generation applied university concept. 
External stakeholders and even members of the board of trustees cannot actively take part in senate, university boards and other executive units. By establishing offices and committees internal and external stakeholders will participate in decision making, implementation and review processes of the university directly or through their representatives.

It is clear that there is a need for solid leadership and coordination in the activities of board of trustees, rector's office, senate, university board and faculty / program committees, new generation offices and committees and boards, competencies and job satisfaction of academic, research and administrative staff in the context of practice-based education, financial and physical facilities and research infrastructure of the university, and satisfaction and expectations of students and stakeholders.

In the traditional university, the rector manages the administrative and financial affairs of the university through the academic and administrative bodies such as senate and university board of directors, and general secretariat and administrative units. However, the complex and nonhierarchical organizational and functional structure envisaged by the new generation practicebased education necessitates institutionalized leadership. Rector's Office should be strengthened and extended through the involvement of leaders of all executive bodies. Rector's Office can be designed as the executive committee, includes managers of the academic and administrative units as well as the managers of the new generation committees / boards and offices. The executive committee, in which the external stakeholders do not participate, will play a critical role in coordinating the activities of the university in all its internal components (Toprak and Bayraktar, 2017).

Figure 1. Organization Chart

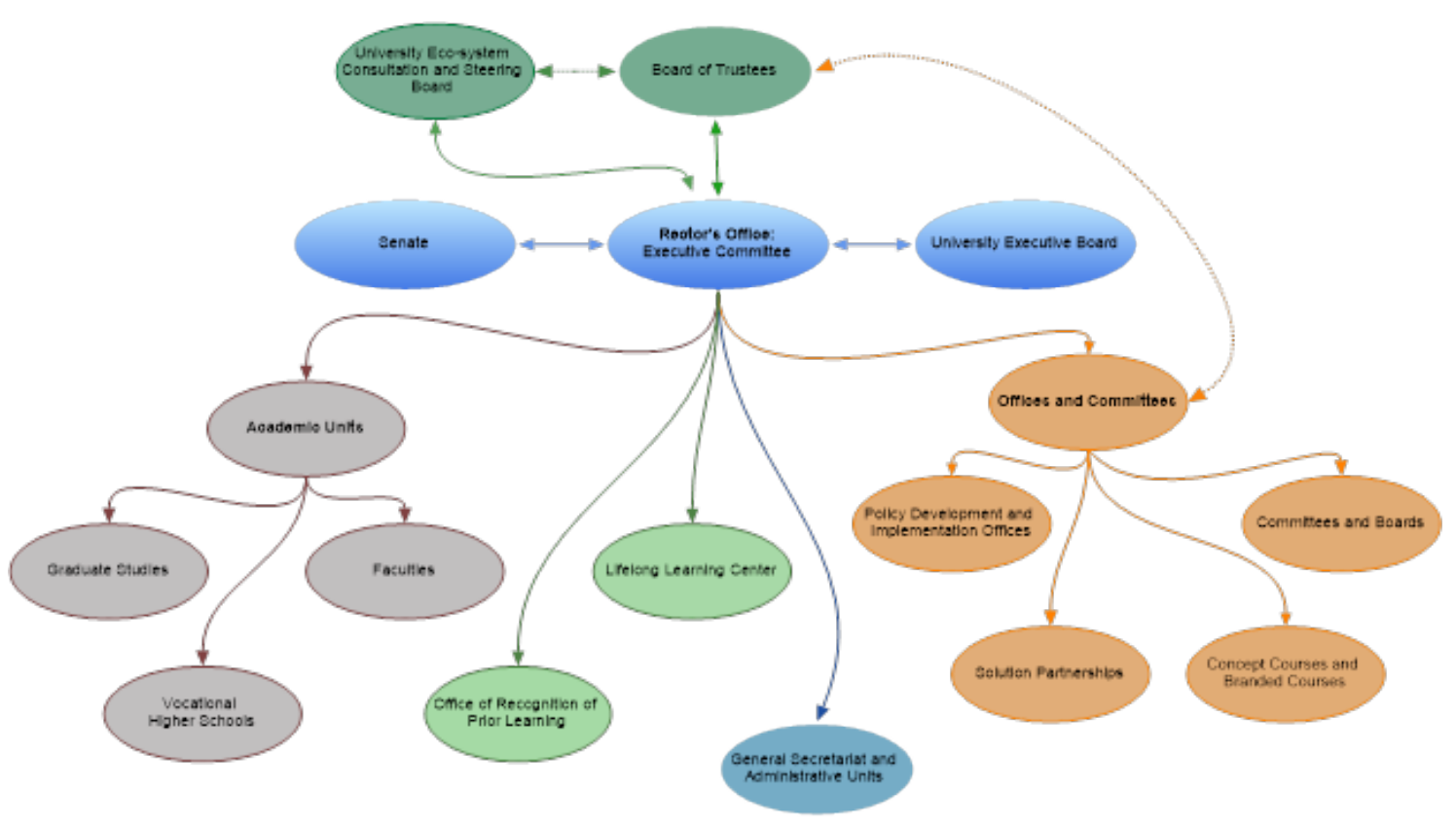

(Foundation University) 


\section{DIMENSIONS OF EVALUATION: CHECKLIST TOOL}

Developing a thematic-technical new generation university model (Toprak et al., 2019) needs to be confirmed by internal and external assessors. Focusing on practice-based education model, not only institutional (internal) bodies but also accreditation \& evaluation agencies will use a tool to ensure that the model proposed is implemented effectively. A checklist with 20 parameters has been developed. Each parameter has different number of items regarding the content and scope of that parameter.

The parameters are composed of variables that can be observable, measurable, periodically trackable, comparable, and usable for accountability, assessing performance, accreditation and institutional evaluation. They include the goal, vision and motto of university; profile(s) of graduate; curriculum design and qualifications framework based on level descriptors (knowledge, skills and competences); program key learning outcomes, course learning outcomes, design of compulsory and elective courses; design of concept courses and branded courses; teaching and learning methods and environments; university capacity in terms of human, physical and financial resources; solution partnerships and stakeholder engagement; and compatibility of governance model.

\section{FUTURE RESEARCH DIRECTIONS}

Developing a new generation model has various implications regarding resources (sufficient finance and other resources allocated in the beginning; depending on students fees; depending on public funds; profit-seeking, non-profit etc..), type (education, research, implementation), field (in the context of ISCED), ownership (private, public, foundation), and operating model (simple hierarchical organization or professionally operated complex organization which necessitates horizontal hierarchical management with effective stakeholder engagement). The first step is to decide aim, vision, type, financial model, field of education and operating model. After establishing and operating the university, the next step will be external assessment (accreditation and institutional evaluation).

In this study a tool has been developed based on experts in various academic fields. The views of experts used here indicate that, if a university is based on the model with the components like thematic, practice-based, stakeholder engagement, and new organizational and functional units, then evaluation tool also would be quite differentiated. Various types of new generation university models would be evaluated based on uniquely developed tool for accreditation and institutional evaluation. Specialization of knowledge production also force knowledge institutions (university) to be assessed specifically.

In the recent couple of years, Turkish Council of Higher Education (CoHE) has initiated new directions for public universities such as research university, mission university with regional development oriented, innovative and entrepreneurial university. The tool for each university type for measuring the performance and identifying the current status are not developed yet. The evaluation model developed here evaluates whole process inputs-process outputs based on outcomes and impact (Kotosz et al., 2016).

Since the function and responsibility of the university institution has not been fully recognized and tracked in the regulations, works on this issue are done by rule of thumb (Estermann and Jorgensen, 2019; Kostosz, 2016). 


\section{CONCLUSION}

It is recommended that the CoHE must develop nation-wide sets of accreditation and evaluation tools for specific types of universities, such as research university, regional development-oriented university, mission university, social sciences university, health sciences university. Here, a tool is proposed for thematic-technical university which prioritizes practice-based education model. After seeing outcomes, it would be possible to conduct an impact analysis and revise the proposed tool.

The assumed missing link between university education and economic development would be much more effectively constructed thru mechanisms and instruments among government, industry and university. In the new generation university understanding, economic development, innovativeness, increased competitiveness and boosting entrepreneurship spirit are proposed mottos for any kind of higher education institutions. Decision making, implementation and review processes in the Turkish higher education and research areas need to be handled in a holistic approach. Otherwise, the gap between economic development and the universities we witness today will last longing. In a digitalized society and economy, it is not possible for a university, which is the main medium of the human resources, to remain outside of the trend. Turkey's governmental system in the context of digitalized society and digitalized government has been changing for two years. As in the EU, the reform agenda of universities in Turkey is fairly loaded. In this study, a checklist has been developed for a thematic university founded in OIZ in order to make quality assurance, accreditation, and review mechanisms more effective.

Organizational and functional architecture of new generation university model is based on the following features: centrally regulated and supervised with the active participation of stakeholders, and autonomously operating units, offices and committees; higher interaction of units and committees; effective stakeholders engagement; high diversity; based on competitiveness; focusing on change \& innovation and a high degree of interdependence; focusing on production and commercialization / branding; adopting the utilitarian philosophy; the outcome-oriented; to equip the alumni with the necessary knowledge and skills to ensure competencies for employability; based on pre-established standards (qualifications framework, professional / occupational standards, core competencies); ensuring quality assurance; high accountability to the community (public) and other stakeholders; focusing on learning by doing and on-the-job training; implementing internationalization as a priority; prioritizing social dimension.

While developing the tool here, various dimensions of practice-based education model have been taken into consideration and internal \& external evaluations would be effectively based on the items in this tool. The previous descriptive framework article (Toprak et al., 2019) and this tool are two complementary instruments to create a holistic approach for the accountability of the model. 


\section{REFERENCES}

[1]Antal, Natalie, Kingma, Bruce, Moore, Duncan and Streeter, Deborah. (2014). University-wide entrepreneurship education. In, Innovative pathways for university entrepreneurship in the 21st century. Published online: 07 October. 227-254. https://doi.org/10.1108/S1048-473620140000024009

[2]Artut, Perihan Dinç and Bal, Ayten Pinar. (2018). Learning implementations about cooperative learning method, a case study in Turkey. International Journal of Progressive Education, 14(6), 168-176. [3]Bacanl, Hasan et al. (2016). Being a university student in turkey: A comparative study in the context of city people, Turkish and international students. Journal of Higher Education. 6(2), 49-61.

[4]Baker, Geoff and Henson, Debra. (2010). Promoting employability skills development in a researchintensive university. Education + Training. 52(1), 62-75.

[5]Barbeau, Joseph E. (1973). Cooperative education in America - its historical development, 19061971. 231p. Northeastern Univ., Boston. https://files.eric.ed.gov/fulltext/ED083913.pdf, (Access: April 5, 2019).

[6]Bizri, Rima, Hammoud, Jamil, Stouhi, Marwa, Hammoud, Manar. (2019). The entrepreneurial university: a proposed model for developing nations. Journal of Management Development. 38(5), 383404.

[7]Block, Madeleine and Khvatova, Tatiana. (2017). University transformation: Explaining policymaking and trends in higher education in Russia. Journal of Management Development. 36(6), 761-779, https://doi.org/10.1108/JMD-01-2016-0020.

[8]Bruton, Alex. (2014). Innovating university-based entrepreneurship in order to inform innovation for the 21st century. In, Innovative pathways for university entrepreneurship in the 21st century, Published online: 7 October, $145-170$.

[9]Cedefop. (2016). Application of learning outcomes approaches across Europe: A comparative study., Cedefop reference series, No. 105, 201p. http://www.cedefop.europa.eu/files/3074_en.pdf, (Accessed: April 1, 2019).

[10]Cedercreutz, Kettil and Cates, Cheryl. (2010). Cooperative education at the University of Cincinnati: A strategic asset in evolution. Peer Review, 12(4), https://www.aacu.org/publicationsresearch/periodicals/cooperative-education-university-cincinnati-strategic-asset, (Accessed: April 1, 2019). [11]Chapleo, Chris and Sims, Chris. (2010). Stakeholder analysis in higher education. Perspectives, January, 14, 12-20.

[12]Cozza, Barbara and Blessinger, Patrick. (2016a). Innovative approaches in university partnerships: An Introduction to university partnerships for academic and program development. In, University partnerships for academic programs and professional development. Published online: 17 August. 3-17. https://doi.org/10.1108/S2055-364120160000007001

[13]Cozza, Barbara and Blessinger, Patrick. (2016b). Pioneering approaches in university partnerships: An introduction to university partnerships for international development. In, University partnerships for international development. Published online: 12 December. 3-17. https://doi.org/10.1108/ S2055-364120160000008001

[14]Deus, Rafael Mattos, Battistelle, Rosane Aparecida Gomesand da Silva, Gustavo Henrique Ribeiro. (2016). Sustainability insights from the mission statements of leading Brazilian universities. International Journal of Educational Management. 30(3), 403-415.

[15]Dewing, Ian P. and Williams, Bernard C. (1995). The role of audit committees in UK universities. Managerial Auditing Journal. 10(6), 10-16, https://doi.org/10.1108/02686909510088369.

[16]Drewery, David, Nevison, Colleen and Pretti, T. Judene. (2016). The influence of cooperative education and reflection upon previous work experiences on university graduates' vocational selfconcept. Education + Training, 58(2), 179-192.

[17]EC. (2008). TUNING - Generic competences, http://www.relint.deusto.es/TuningProject/index.htm, (Erişim, 1 Eylül 2018).

[18]EC. (2010). Europe 2020: European strategy for smart, sustainable and inclusive growth. http:// 
ec.europa.eu/eu2020/pdf/COMPLET\%20EN\%20BARROSO $\% 20 \% 20 \% 20007 \% 20$-\%20Europe \%20 2020\%20-\%20EN\%20version.pdf, (Erişim, 26 Eylül 2018).

[19]EHEA. (1998). Sorbonne Joint Declaration.

[20]EHEA. (2018a). European higher education area and Bologna Process. http://ehea.info/pagequalification-frameworks, (Erişim, 1 Nisan 2019).

[21]EHEA. (2018b). The European higher education area in 2018. https://eacea.ec.europa.eu/nationalpolicies/eurydice/sites/eurydice/files/bologna_internet_0.pdf, (Erişim, 3 Eylül 2018).

[22]EHEA. (2019). The Bologna process revisited: The future of the European higher education area. http://ehea.info/media.ehea.info/file/2015_Yerevan/71/1/Bologna_Process_Revisited_Future_of_the_ EHEA_Final_613711.pdf, (Erişim, 1 Nisan 2019).

[23]Erdoğan, Armağan and Toprak, Metin. (2012). Governance of higher education in Turkey. Leadership and governance in higher education, 3, 95-120.

[24]Erdoğan, Armağan and Toprak, Metin. (2014). What kind of higher education? References, scope and tools. Yeni Turkiye, 58(May-June), 707-718.

[25]Estébanez, Raquel Pérez. (2017). An approachment to cooperative learning in higher education, comparative study of teaching methods in engineering. EURASIA Journal of Mathematics Science and Technology Education, 13(5),1331-1340.

[26]Estermann, Thomas and Jorgensen, Thomas. (2019). Enabling frameworks: What universities need in the age of open innovation? https://www.eua.eu/resources/expert-voices/102:enablingframeworks-what-universities-need-in-the-age-of-open-innovation.html (Accessed: June 24, 2019).

[27]Etzkowitz, Henry and Dzisah, James. (2013). Bottom-up Triple Helix: science policy in the states of the USA. Journal of Knowledge-based Innovation in China. 5(2), 80-96.

[28]Farnsworth, Terry. (1970). How to select external courses. Industrial and Commercial Training, 2(6), 262-264.

[29]Galvão, Anderson et al. (2017). A quadruple helix model of entrepreneurship, innovation and stages of economic development. Review of International Business and Strategy. 27(2), 261-282.

[30]Gartland, Clare Elizabeth and Smith, Christine. (2018). Supporting progression to HE: the role of colleges and vocational courses. Education + Training, 60(6), 637-650.

[31]Haddara, Mahmoud and Skanes, Heather. (2007). A reflection on cooperative education, from experience to experiential learning. Asia-Pacific Journal of Cooperative Education, 8(1), 67-76.

[32] Hasan, Mahmudul, Khan, Eijaz Ahmed and Un Nabi, Noor. (2017). Entrepreneurial education at university level and entrepreneurship development, Education + Training. 59(7/8), 888-906.

[33] Holtzman, Diane and Kraft, Ellen. (2011). Skills needed in the 21st century workplace: A comparison of feedback from undergraduate business alumni and employers with a national study. Business Education \& Accreditation, 3(1), 61-76.

[34]Johnson, David W., Johnson, Roger T. and Holubec, Edythe Johnson. (2008). The new circles of learning: Cooperation in the classroom, Edina, MN, Interaction Book Company.

[35]Johnson, David W., Johnson, Roger T. and Smith, Karl A. (2013). Cooperative learning: Improving university instruction by basing practice on validated theory, University of Minnesota, 26p., (Accessed: September 1, 2018).

[36]Kireçci, Mehmet Akif et al. (2016). "The internationalization of higher education in Turkey: Creating an index”. Education and Science, 41(187),1-28.

[37]Kotosz, Balazs et al. (2016). How to measure the local economic impact of universities? Methodological Overview. Online at https://mpra.ub.uni-muenchen.de/73725/ MPRA Paper No. 73725, posted 23 September 2016 09:04 UTC.

[38]Kulkarni, Sharvari and Kulkarni, D.G. (2019). Gap analysis of Soft skills in the curriculum of higher education: A case study of management institutes in Karnataka. Advances in Management, 12(1), 64-67.

[39]Lee, JungEun. (2011). The capitalization of knowledge: A triple helix of university-industrygovernment. Journal of Educational Administration. 49(3), 345-348.

[40]Liu, Chunlin and Kong, Lanlan. (2015). Government-driven university-industry linkages in an emerging country: the case of China. Journal of Science \& Technology Policy Management, 6(3), 263-282. 
[41]Liu, Ye. (2012). Does entrepreneurial university really exist in China? A case from Huazhong University of Science and Technology. Journal of Knowledge-based Innovation in China. 4(2), 88-103.

[42]Lombardi, Rosa, Massaro, Maurizio, Dumay, John and Nappo, Fabio. (2019). Entrepreneurial universities and strategy: the case of the University of Bari. Management Decision, https://doi.org/10.1108/ MD-06-2018-0690.

[43]Lu, Lucy. (2008). Creating knowledge-based innovation in China: The strategic implications of triple helix model. Journal of Technology Management in China. 3(3), 249-263.

[44]Macpherson, Reynold J.S. (1997). The centre for professional development at the University of Auckland: Towards creating networks of moral obligations. International Journal of Educational Management, 11(6), 260-267.

[45]Marri, H.B. Grieve, R.J., Gunasekaran, A. and Kobu, B. (2002). Government-industry-university collaboration on the successful implementation of CIM in SMEs: An empirical analysis. Logistics Information Management. 15(2), 105-114.

[46]McRae, Norah and Ramji, Karima. (2017). Intercultural competency development curriculum: A strategy for internationalizing work-integrated learning for the 21st century global village. WorkIntegrated Learning in the 21st Century, Published online: 29 August, 129-143.

[47]Murphy, Anne. (2011). The capitalization of knowledge: A triple helix of university-industrygovernment. Leadership \& Organization Development Journal. 32(6), 648-651.

[48]OECD-IMHE. (2009). Higher education management and policy, programme on institutional management. http://www.oecd.org/education/imhe/50309916.pdf, (Erişim,1 Eylül 2018).

[49]Olsson, Ulf. (2016). Open courses and MOOCs as professional development - is the openness a hindrance? Education + Training. 58(2), 229-243.

[50]Ostim Technical University. (2018). The Statute of the Ostim Technical University. Official Gazette, December.

[51]Otala, Leenamaija. (1994). Industry-university partnership: implementing lifelong learning. Journal of European Industrial Training, 18(8), pp.13-18.

[52]Patton, Narelle. (2017). Driving change, students shaping and reshaping work-integrated learning spaces. Work-Integrated Learning in the 21st Century. Published online: 29 August, 163-176.

[53]Piirainen, Kalle Artturi, Andersen, Allan Dahl and Andersen, Per Dannemand. (2016). Foresight and the third mission of universities: the case for innovation system foresight. Foresight. 18(1), 24-40.

[54]Poon, Joanna and Brownlow, Michael. (2015). Development of students' commercial awareness within the curriculum of professionally accredited courses: A case study of property courses. Education + Training, 57(4), 405-428.

[55]Reyes, Charisse N. (2016). Framing the entrepreneurial university: the case of the National University of Singapore. Journal of Entrepreneurship in Emerging Economies. 8(2), 134-161.

[56]Rubens, Arthur, Spigarelli, Francesca, Cavicchi, Alessio and Rinaldi, Chiara. (2017). Universities' third mission and the entrepreneurial university and the challenges they bring to higher education institutions. Journal of Enterprising Communities: People and Places in the Global Economy. 11(03), 354372.

[57]Savignon, Andrea Bonomi, Corvo, Luigi. (2018). Government-third sector relations and the triple helix approach: Patterns in the Italian social innovation ecosystem, Studies in Public and NonProfit Governance. 6, 95-109.

[58]Scalia, Massimo et al. (2018). Governance for sustainability: a triple-helix model. Sustainability Science. Published online: May 11. https://doi.org/10.1007/s11625-018-0567-0.

[59]Shapiro, Hanne, Lauritzen, John René Keller and Irving, Pat. (2011). Emerging skills and competences- a transatlantic study: EU-US study for the European Commission, October, Danish Technological Institute, $141 \mathrm{p}$.

[60]Sheety, Alia et al. (2016). University partnerships for academic program and professional development, building faculty capacity for 21st century teaching and learning. University Partnerships for Academic Programs and Professional Development. Published online: 17 August, 221-241.

[61]Striukova, Ludmila and Rayna, Thierry. (2015). University-industry knowledge exchange: An 
exploratory study of open innovation in UK universities. European Journal of Innovation Management, 18(4), 471-492.

[62]Sumanjeet, Singh. (2012). Developing e-skills for competitiveness, growth and employment in the 21st century: The European perspective. International Journal of Development Issues, 11(1), 37-59.

[63]Toprak, Metin and Bayraktar, Yüksel. (2017). Corporate governance practices of Turkey, A critical review, The IUP Journal of Corporate Governance, XVI(2), 54-75.

[64]Toprak, Metin and Erdoğan, Armağan. (2012). Lifelong Learning: Concept, policy, instruments and implementation. Journal of Higher Education and Science, 2(2), 69-91.

[65]Toprak, Metin and Erdoğan, Armağan. (2013). European approach to graduate studies. 6th national graduate education symposium proceedings. Sakarya University Institute of Educational Sciences. 10-36.

[66]Toprak, Metin et al. (2019). New generation university: An organizational and functional governance model proposal for a thematic-technical university. Journal of Higher Education. Forthcoming, (2019 fall).

[67]Toprak, Metin, Erdoğan, Armağan and Açıkgöz, Ömer. (2013). Field qualifications: A framework suggestion. The New Educational Review. 31(1), 153-164.

[68]Ughetto, Elisa. (2007). Foresight as a triple helix of industry, university and government relations. Foresight. 9(5), 14-22.

[69]van Weenen, Hans. (2000). Towards a vision of a sustainable university. International Journal of Sustainability in Higher Education, 1(1), 20-34.

[70]Wagenaar, Robert. (2016). Modernisation of education II, education policy and programme, innovation, EIT and MSCA. Developing future skills in higher education, ET2020 - Peer learning activity (PLA). Brussels, 25-26 February, Key Findings, http://cced-complete.com/documentation/ developing_future_skills_in_higher_education_eng.pdf, (Accessed: September 10, 2018).

[71]Wagner, Tony. (2009). The global achievement gap. New York, Perseus Books Group, 344p. https:// archive.org/details/globalachievemen00wagn/page/n5, (Accessed: April 15, 2019).

[72]Yang, Yan and Holgaard, Jette Egelund. (2012). The important role of civil society groups in ecoinnovation: a triple helix perspective. Journal of Knowledge-based Innovation in China. 4(2), 132-148.

[73] Zhou, Chunyan. (2008). Emergence of the entrepreneurial university in evolution of the triple helix: The case of Northeastern University in China. Journal of Technology Management in China. 3(1), 109-126. 


\section{APPENDIX}

\section{A.1.CRITERIA FRAMEWORK FOR EVALUATING THE DESIGN AND PERFORMANCE OF PRACTICE-BASED EDUCATION}

1. the degree to which the design of the graduate profile allows for the practice-based education model;

2. the degree to which the compulsory-elective course ratio and its design allow for the practicebased education model;

3. the degree to which the design of the concept and branded courses and form of acquisition of their learning outcomes allow for the practice-based education model;

4. compatibility level of the design of the practice-based education model in the diploma \& certificate forms with the vision and aims of the university;

5. The degree to which the physical, financial and infrastructural facilities of the University permit the practice-based education model;

6. the degree to which the academic and research staff of the university allow for the practicebased education model;

7. the degree to which the design of the higher education qualifications framework (QF) allows for the practice-based education model;

8. the degree to which the design of the program key learning outcomes (PKLOs) allows for the practice-based education model;

9. the degree to which the learning outcomes of the courses (LOs) allow for the practice-based education model;

10. the degree to which the design of the solution partnerships allows for the practice-based education model;

11. the degree to which the design of the teaching and learning ways of courses allow for the practice-based education model;

12. The degree to which the design of the boards and the committees allows for the practice-based education model;

13. the degree to which the offices of the policy development and implementation allow for the practice-based education model;

14. The degree to which the governance model of the university allows for the practice-based education model. 


\section{A.2. COMMITTEES / BOARDS AND RELATED TARGET GROUPS / STAKEHOLDERS}

\begin{tabular}{|c|c|}
\hline Committee / board & Related / Targeted group \\
\hline University ecosystem consultation and steering board & $\begin{array}{l}\text { I. Board of Trustees and Rector's } \\
\text { Office }\end{array}$ \\
\hline Executive committee (Rector's Office) & II. Rector's Office \\
\hline Committee for the recognition and transfer of prior learning & III. Workpeople: Industry \\
\hline Learning management systems committee & IV. Students \\
\hline \multicolumn{2}{|l|}{ Coop-education committee } \\
\hline \multicolumn{2}{|l|}{ Professional / vocational qualifications committee } \\
\hline \multicolumn{2}{|l|}{ Foreign language committee } \\
\hline \multicolumn{2}{|l|}{ Individual learning support committee } \\
\hline \multicolumn{2}{|l|}{ Entrepreneurship and leadership committee } \\
\hline \multicolumn{2}{|l|}{ Joint degree programs committee } \\
\hline \multicolumn{2}{|l|}{ Scholarship students committee } \\
\hline \multicolumn{2}{|l|}{ Student council } \\
\hline \multicolumn{2}{|l|}{ Student clubs } \\
\hline \multicolumn{2}{|l|}{ Curriculum committee } \\
\hline Research and project steering committee & V. Personnel: Academicians \\
\hline \multicolumn{2}{|l|}{ Research, project, publication and social activity promotion committee } \\
\hline \multicolumn{2}{|l|}{ Committee for the appointment and promotion of academic staff } \\
\hline \multicolumn{2}{|l|}{ Academic staff performance evaluation committee } \\
\hline Equality of opportunity and ethics affairs board & $\begin{array}{l}\text { VI. Personnel: Academic and } \\
\text { administrative staff }\end{array}$ \\
\hline \multicolumn{2}{|l|}{ Human resources committee } \\
\hline Administrative staff appointment and promotion committee & VII. Personnel: Administrative \\
\hline \multicolumn{2}{|l|}{ Administrative staff performance evaluation committee } \\
\hline Application and complaint monitoring committee & $\begin{array}{l}\text { VIII. University: Academic and } \\
\text { administrative units, offices, committees } \\
\text { / boards }\end{array}$ \\
\hline \multicolumn{2}{|l|}{ Website monitoring committee } \\
\hline Committee on business development and cooperation with stakeholders & $\begin{array}{l}\text { IX. University: Industrialists and } \\
\text { business world }\end{array}$ \\
\hline Committee of clusters & $\begin{array}{l}\text { X. University: Clusters' associations, } \\
\text { industrialists and business world, } \\
\text { study programs' curricula and learning } \\
\text { systems }\end{array}$ \\
\hline \multicolumn{2}{|l|}{ Digital agenda committee } \\
\hline European Higher Education Area compliance committee & $\begin{array}{l}\text { XI. University: Diploma and } \\
\text { certificate programs }\end{array}$ \\
\hline \multicolumn{2}{|l|}{ Quality assurance and accreditation committee } \\
\hline Internal control and internal audit committee & $\begin{array}{l}\text { XII. University: Administrative units, } \\
\text { offices, committees / boards }\end{array}$ \\
\hline Exchange programs committee & $\begin{array}{l}\text { XIII. University: Students, academic } \\
\text { and administrative staff }\end{array}$ \\
\hline \multicolumn{2}{|l|}{ Committee for disadvantaged persons } \\
\hline Information management committee & $\begin{array}{l}\text { XIV. University: Software \& hardware } \\
\text { and data management }\end{array}$ \\
\hline Diversity committee & \\
\hline
\end{tabular}




\section{A.3. CHECKLIST: DIMENSIONS OF EVALUATION}

1. There are several items to be evaluated in the following dimensions. The number and content of dimensions under each item vary depending on the type of university, such as research university, teaching college, professional / vocational oriented university or college, and regional development-oriented mission university.

2. Motto of the university

3. University's vision and purpose (criterium to be taken as benchmark).

4. The consolidated performance of the practice-based education model (summary: 20 dimensions).

5. Identifying the graduate profile in accordance with practice-based education model (4 profiles).

6. Dimensioning the curriculum in terms of knowledge, skills and competence (3 dimensions).

7. The ways courses are taught ( 6 ways).

8. Compatibility of practice-based education with the vision and purpose of the university designed in the qualification description form (9 items).

9. Compatibility of the physical / financial / infrastructure capacity and the academic / researcher capacity of the university with the practice-based education model (5 items).

10. Compatibility of TR-HE-QF with the practice-based education model (5 items).

11. Compatibility of program key learning outcomes with the practice-based education model (15 items).

12. Compatibility of the relationship of PKLOs and TR-HE-QF with the practice-based education model.

13. Compatibility of CLOs with the practice-based education model (18 items).

14. Compatibility of the relationship of CLOs and PKLOs with the practice-based education model.

15. Compatibility of determining of ratios of compulsory and elective courses with the practicebased education model.

16. Consistency of the relationship of compulsory and elective courses in the context of the practicebased education model (4 items).

17. Consistency the design and feasibility of solution partnerships within the context of the practice-based education model (7 items).

18. Proportion of concept courses and branded courses within the curriculum.

19. Contribution of the concept courses in the format of solution partnerships to the practicebased education model (10 items).

20. Contribution of the branded courses in the format of solution partnerships to the practicebased education model (19 items).

21. Contribution of the committees and boards to the practice-based education model (8 items).

22. Contribution of the policy development and implementation offices to the practice-based education model (8 items).

23. Contribution of the governance model (organization, coordination and leadership) to the operation of the practice-based education model ( 20 items). 